BOTANICA

ISSN 2538-8657

2020, 26(2): 150-159

\title{
HERITABILITY PATTERNS OF SOME AGRO-BOTANICAL CHARACTERS RELATED TO YIELD AND DROUGHT TOLERANCE IN TWO LANDRACES OF RICE
}

\author{
Olubukola Grace Abraham ${ }^{1 *}$, Chinyere Constance Nwokeocha ${ }^{2}$, Julius Olaoye FaluYi \\ ${ }^{1}$ Obafemi Awolowo University, Department of Botany, BC220005, P.M.B. 13, Ile-Ife, Nigeria \\ ${ }^{2}$ Obafemi Awolowo University, Natural History Museum, BC220005, P.M.B. 13, Ile-Ife, Nigeria \\ *Corresponding author. E-mail: graceolubukola1105@gmail.com
}

\begin{abstract}
Abraham O.G., Nwokeocha C.C., Faluyi J.O., 2020: Heritability patterns of some agro-botanical characters related to yield and drought tolerance in two landraces of rice. - Botanica, 26(2): 150-159.

Two landraces of rice, AWGUII-04 and IJ-124, were characterised and assessed for phenotypic variability, heritability, genetic advance and modes of inheritance of some primary yield and drought-tolerance traits. The target traits for yield were a percentage of filled spikelets, plant form, tillering, and for drought tolerance, leaf rolling, ratooning and maturity. This study was carried out to help both breeders and farmers make a wise choice when carrying out hybridisation and on the field. Hybridisation produced three $\mathrm{F}_{1}$ hybrids that were advanced to $\mathrm{F}_{2}$ generation. Quantitative and qualitative vegetative and reproductive data were taken from each $\mathrm{F}_{2}$ population. The results obtained showed high heritability $(62-100 \%)$ in all the thirty-eight vegetative and reproductive traits. The genetic advance was high $(>20 \%)$ in all the target traits except for leaf rolling. The traits segregated in the following ratio: plant growth form - 9:6:1; the percentage of filled spikelets - 13:3; ratooning $-3: 1$; maturity $-15: 1$; the number of tillers $-15: 1$ and leaf rolling $-15: 1$. The high heritability of the above traits makes them highly dependable for rice crop improvement.
\end{abstract}

Keywords: breeding, drought-tolerance, fertility, genetic inheritance, hybridisation, rice, yield.

\section{INTRODUCTION}

Rice, Oryza sativa Linn., is one of the most widely-consumed food crops next to maize. Its cultivation and production have, however, been reported to be declining due to climate changes through drought, heatwaves, flooding, pests and diseases (RosENZWEIG et al., 2000). The yield loses recorded ranged from 15-50\% (PANDEY \& Bhandari, 2009; SRIVIDHYa et al., 2011).

Landraces of rice have been reported to benefit from several introgressive hybridisation of locallyproduced rice with their wild relatives, which occur on the fields of local farmers who unconsciously harvest the resulting hybrids and carry them into advanced generations (FAluyi \& Nwokeocha, 1993). According to Faluyi \& NwOKeocha (1993), most of the times, farmers recognise these hybrids as offtypes, which they leave on the field without harvesting. These off-types eventually introgress with cultivated rice the next season, and the resulting hybrids may become harvested along with the cultivated rice, with their genomes redefined. This has helped to increase the genetic base of locally-produced rice, making them especially fit into local agro-ecologies coupled with the fact that local farmers have some basic knowledge of the biology of these different landraces. It is, therefore, not surprising that rice landraces are better adapted and have acceptable yield potentials compared to newly-introduced improved varieties, when cultivated under minimal cultural regimens (Faluyi \& NwOKEOCHA, 1993; Zeven, 1998). Hybridisation has been shown to play an important role in the evolution of Oryza species over 
the ages as hybrid swarms have been reported by researchers in different parts of the world (Ока \& CHU, 1970; SANo et al., 1984; GHesquiere, 1986; BolaJI \& NwoKeocha, 2013).

The cultivated rice is an annual plant with desirable agro-botanical characters such as hardiness, high yield and drought-tolerance. At the same time, the wild species are perennial, mainly because they can ratoon profusely even after they have completed their normal life cycle. The Nigerian landraces have been reported by some researchers as having perennial habit by the production of new shoots from the rootstock after completing their life cycle (NWOKEOCHA et al., 2007), and sometimes, they ratoon at the nodes just above the ground level. This ability of the landraces has made it possible for farmers to harvest grains beyond the standard, harvesting period, as long as water and other favourable environmental conditions prevail.

Productivity or yield of rice is determined by many factors, including the availability of light, water, nutrients and planting density (BALOCH et al., 2002; FAGERIA et al., 2011). Also, the plant architecture (tillering pattern and plant morphology, plant height, leaf shape and arrangement) and panicle architecture (number and length of primary, secondary and tertiary branches, number of spikelets per branch, length and breadth of spikelets) play significant roles in the overall grain production of the rice plant. Yield can also be measured by the total number or weight of grains, as it has been established by ABRAHAM et al. (2017) that rice show trade-offs between the number and weight of grains.

Also, many studies have pointed to the efficiency of some traits such as days to booting and maturity as well as percentage fertility as highly heritable and responsive to selection in hybrid populations (KUMAR et al., 2018; Tripathy et al., 2018). Afiukwa et al. (2016) have assessed some landraces in conjunction with improved varieties of rice for DNA polymorphism using SSR markers for drought-tolerance. The promising landraces in their investigation were IJsllw-09, IJsllw-02, IKPh ${ }^{+}$-PS and $\mathrm{IKPh}^{+}$-FS, which have been extensively characterised by UMUNNAKWE (2015) and ABRAHAM (2016). These landraces have unique alleles with FARO-11 (an established drought-tolerant variety) and even performed better under drought conditions (AfIUKWA et al., 2016).
However, there is a scarcity of information on the inheritance pattern of the significant agro-botanical characters that determine rice yield and drought tolerance, making it difficult for breeders and farmers to follow or plan hybridisation adequately. The present study, therefore, exploited the rich genetic base of the landraces by involving them in a hybridisation experiment to determine the heritability of some of these traits as well as their modes of inheritance in hybrid populations.

\section{MATERIALS AND METHODS}

The study commenced with planting and hybridisation in April 2016. The parents (IJ-124 and AWGUII-04) were selected from accessions previously characterised by AfIUKWA et al. (2016) and ABRAHAm et al. (2017) based on yield and droughttolerance traits. Landrace IJ-124 exhibit the same morphological characteristics as IJsllw-09, which had been earlier identified as a drought-tolerant accession by AfIUKWA et al. (2016), and AWGUII-04 is not drought tolerant, but is a high-tillering plant with high yield (Table 1). Both parents (IJ-124 and AWGUII-04) were crossed, and three $F_{1}$ hybrids were obtained.

The $\mathrm{F}_{2}$ seeds obtained from the $\mathrm{F}_{1}$ plants were advanced to the $F_{2}$ generation in August 2017. The seeds were directly sown in the open field under rainfed conditions. They were planted one plant per hill at a spacing of $25 \times 25 \mathrm{~cm}$ between rows and $50 \mathrm{~cm}$ between block, where a block represented a single $\mathrm{F}_{2}$ population. Data included twenty-four vegetative and fourteen reproductive characters. Each character was classified according to the BIODIVERSITY INTERNATIONAL et al. (2007) or using the authors' discretion, when the characters were not well-defined. The characters investigated are listed below:

a) culm angle: erect, intermediate, open, spreading or procumbent;

b) colour of the leaf sheath, flower, collar, auricle, hull and caryopsis;

c) leaf pubescence: glabrous, intermediate or pubescent;

d) days to booting (days from seeding to boot);

e) maturity (days from seeding to when more than $85 \%$ of the grains are fully ripened);

f) culm height (measured from the soil level to the 
ciliate ring);

g) leaf length and breadth (for the flag and the penultimate leaves of the main culm);

h) length of ligule (average of 5 ligules on the same level on the plant);

i) leaf rolling (for drought tolerance);

j) ratooning (stay-green or new tiller production after plant death);

k) panicle characters (length, exertion).

Panicle parameters were measured for further characterisation, according to FUTSUHARA et al. (1979a, b). They were the following:

i. length of panicle (from the ciliate ring to the tip of the last grain; awns excluded);

ii. rachis length (from the ciliate ring to the base of the last primary branch);

iii. number and length of primary, secondary and tertiary (where present) branches;

iv. number of spikelets (taking into account the number of filled and unfilled ones.).

The percentage of fertility was calculated using the following formula:

Fertility $(\%)=\frac{\text { Number of filled spikelets }}{\text { Total number of spikelets }} \times 100$

Broad-sense heritability, genotypic and phenotypic coefficients of variation (GCV and PCV) and percentage genetic advance (GA) were calculated according to the formula provided by AHMAD et al. (2016).

$$
\begin{gathered}
\text { Heritablity }\left(H^{2}\right)=\left(\frac{V g}{V p}\right) \times 100=\left(\frac{V g}{V g+V e}\right) \times 100 \\
V g(\text { genetic variance })=V_{2}-\mathrm{Ve},
\end{gathered}
$$$$
\mathrm{Ve}(\text { environmental variance })=\frac{\mathrm{VP}_{1}+\mathrm{VP}_{2}+\mathrm{VF}_{1}}{3},
$$

$\mathrm{VP}_{1}=$ variance of parent $1, \mathrm{VP}_{2}=$ variance of parent $2, \mathrm{VF}_{1}=$ variance of $\mathrm{F}_{1}$, and $\mathrm{VF}_{2}=$ variance of $\mathrm{F}_{2}$. $\mathrm{GCV}$ and $\mathrm{PCV}$ were calculated using the following formulas:

$$
\begin{aligned}
\mathrm{GCV} & =\frac{\sqrt{V g}}{\bar{X}_{F_{2}}} \\
\mathrm{PCV} & =\frac{\sqrt{V p}}{\bar{X}_{F_{2}}}
\end{aligned}
$$

where $\bar{X}_{F_{2}}=$ grand mean of $\mathrm{F}_{2}$.

Genetic advance was calculated according to the formula:

$$
G A=\frac{i \sigma p}{\bar{X}_{F_{2}}} \times 100
$$

$i$ is a constant $-2.06, \sigma p-$ phenotypic standard deviation.

The goodness-of-fit test was used to determine the conformity of six yield and drought-tolerance related traits to classical segregation ratios. Chi-square was calculated according to the following formula:

$$
\text { Chi-square }=\frac{\left(o^{2}-e^{2}\right)^{2}}{e^{2}} \text {. }
$$

\section{RESULTS AND DISCUSSION}

\section{Heritability, genotypic and phenotypic coeffici- ents of variation, and genetic advance}

The results displayed that all the vegetative and reproductive characters had high heritability (Table 2 and 3$)$. The broad-sense heritability $\left(\mathrm{H}^{2}\right)$ has been characterised by Robinson (1966) into high $(>75 \%)$, medium (50-75\%) and low $(<50 \%)$, while GA $>20 \%$ was considered high (KuMAR et al., 2018). Among the thirty-eight vegetative traits studied, only the breadth of flag leaf had heritability lower than $50 \%(38 \%)$, while the heritability of the other traits was well above $60 \%$ (Table 2 ). The number of days to maturity had the least GCV and PCV (7.26 and 7.53\%, respectively), while the total number of tillers had the highest GCV and PCV (46.6 and 52.41\%, respectively). Despite the low GCV and PCV of the number of days to maturity, it, however, had high heritability of $93 \%$. The results from this study support the previous findings (Suman et al., 2005; SingH et al., 2007; SinGH et al., 2008; Sarangui et al., 2009; AKInWale et al., 2011; Kumar et al., 2018; Tripathy et al., 2018).

The number and total length of tertiary branches had negative heritability stemming from the fact that the high parent for both traits (AWGUII-04) had very high variance, thereby making the $\mathrm{Vg}$ for both traits negative values. However, both (number and length of tertiary branches) had the highest PCV and GCV (Table 3).

In this study, six characters were associated with yield and drought tolerance, that is, percentage of filled spikelets, culm length, number of days to maturity, number of tillers, leaf coiling and ratooning had high percentages of heritability $(94,79,93,79,100$ 
Table 1. Parental materials used in the study

\begin{tabular}{|c|c|c|c|l|l|}
\hline S/N & Name & Location & Status & \multicolumn{1}{|c|}{ Remarks } & \multicolumn{1}{c|}{ Collector(s) } \\
\hline 1. & IJsllw-09/IJ-124 & Ekiti State & Landrace & $\begin{array}{l}\text { Tall, early, perennial, drought-tolerant, long white } \\
\text { grains, long panicle }\end{array}$ & $\begin{array}{l}\text { Faluyi \& } \\
\text { Nwokeocha (1985) }\end{array}$ \\
\hline 2. & AWGUII-04 & Enugu State & Landrace & $\begin{array}{l}\text { Short, annual, high tillering, compact, moderate } \\
\text { maturity, high spikelet number, short dense panicle }\end{array}$ & $\begin{array}{l}\text { Umunnakwe } \\
(2013)\end{array}$ \\
\hline
\end{tabular}

Table 2. Estimates of variance and genetic parameters for twenty-four vegetative traits of rice landraces

\begin{tabular}{|c|c|c|c|c|c|c|c|c|c|c|c|}
\hline Traits & $\begin{array}{c}\mathrm{IJ}-124 \\
\text { variance }\end{array}$ & $\begin{array}{c}\text { AWGUII-04 } \\
\text { variance }\end{array}$ & $\begin{array}{c}\mathrm{F}_{1} \\
\text { Variance }\end{array}$ & $\mathrm{Vp}$ & $\mathrm{Ve}$ & $\mathrm{Vg}$ & $\mathrm{H}^{2}(\%)$ & $\begin{array}{c}\mathrm{F}_{2} \\
\text { mean }\end{array}$ & $\begin{array}{l}\mathrm{PCV} \\
(\%)\end{array}$ & $\begin{array}{l}\text { GCV } \\
(\%)\end{array}$ & $\begin{array}{l}\text { GA } \\
(\%)\end{array}$ \\
\hline Leaf pubescence & 0.00 & 0.00 & 0.00 & 0.69 & 0.00 & 0.69 & 100 & 1.96 & 42.35 & 42.35 & 72.55 \\
\hline $\begin{array}{l}\text { Pigmentation of outer } \\
\text { leaf sheath }\end{array}$ & 0.00 & 0.00 & 0.00 & 0.13 & 0.00 & 0.13 & 100 & 1.12 & 32.81 & 32.81 & 24.75 \\
\hline $\begin{array}{l}\text { Pigmentation of inner } \\
\text { leaf sheath }\end{array}$ & 0.00 & 0.00 & 0.00 & 0.14 & 0.00 & 0.14 & 100 & 1.12 & 33.13 & 33.13 & 25.27 \\
\hline Days to booting & 7.44 & 1.04 & 1.56 & 74.33 & 3.35 & 70.99 & 95.0 & 83.47 & 10.33 & 10.09 & 175.20 \\
\hline Days to maturity & 1.36 & 6.96 & 8.00 & 78.22 & 5.44 & 72.78 & 93.0 & 117.48 & 7.53 & 7.26 & 127.62 \\
\hline Panicle synchronization & 0.00 & 0.00 & 0.00 & 0.22 & 0.00 & 0.22 & 100 & 1.34 & 35.35 & 35.35 & 34.48 \\
\hline Stigma colour & 0.00 & 0.00 & 0.00 & 0.01 & 0.00 & 0.01 & 100 & 1.01 & 10.23 & 10.23 & 2.17 \\
\hline Flag leaf angle & 0.00 & 0.00 & 0.00 & 0.93 & 0.00 & 0.93 & 100 & 2.00 & 48.31 & 48.31 & 96.16 \\
\hline Panicle type & 0.00 & 0.00 & 0.00 & 0.09 & 0.00 & 0.09 & 100 & 1.90 & 15.82 & 15.82 & 9.80 \\
\hline Panicle exserti & 0.00 & 0.00 & 0.00 & 0.71 & 0.00 & 0.71 & 100 & 2.91 & 28.93 & 28.93 & 50.20 \\
\hline Plant form & 0.00 & 0.00 & 0.00 & 0.33 & 0.00 & 0.33 & 100 & 1.66 & 34.66 & 34.66 & 41.12 \\
\hline Culm length & 136.72 & 12.57 & 0.20 & 239.85 & 49.83 & 190.02 & 79.0 & 56.79 & 27.27 & 24.27 & 689.23 \\
\hline Number of tillers & .16 & 0.64 & 0.22 & 1.63 & 0.34 & 1.29 & 79.0 & 2.44 & 52.41 & 46.61 & 109.01 \\
\hline Apiculus pigmentation & .00 & 0.00 & 0.00 & 0.03 & 0.00 & 0.03 & 100 & 1.03 & 17.79 & 17.79 & 6.71 \\
\hline Awning & 0.00 & 0.00 & 0.00 & 0.09 & 0.00 & 0.09 & 100 & 1.89 & 16.26 & 16.26 & 10.31 \\
\hline Hull colour & 0.00 & 0.00 & 0.00 & 0.50 & 0.00 & 0.50 & 100 & 2.55 & 27.68 & 27.68 & 40.32 \\
\hline $\begin{array}{l}\text { Length of penultimate } \\
\text { leaf }\end{array}$ & 37.48 & 3.85 & 131.23 & 164.44 & 57.52 & 106.93 & 65.0 & 53.02 & 24.19 & 19.50 & 415.46 \\
\hline $\begin{array}{l}\text { Breadth of penultimate } \\
\text { leaf }\end{array}$ & 0.02 & 0.01 & 0.00 & 0.09 & 0.01 & 0.08 & 89.0 & 1.31 & 23.61 & 22.24 & 13.30 \\
\hline Length of flag leaf & 52.68 & 9.53 & 52.92 & 99.18 & 38.37 & 60.80 & 61.0 & 38.11 & 26.13 & 20.46 & 328.64 \\
\hline Breadth of flag leaf & 0.02 & 0.01 & 0.16 & 0.10 & 0.06 & 0.04 & 38.0 & 1.56 & 20.51 & 12.71 & 5.20 \\
\hline Mean ligule length & 0.08 & 0.04 & 0.07 & 0.16 & 0.06 & 0.10 & 63.0 & 1.80 & 22.61 & 17.95 & 11.92 \\
\hline Pigmentation at maturity & 0.00 & 0.00 & 0.00 & 0.05 & 0.00 & 0.05 & 100 & 1.05 & 21.13 & 21.13 & 9.68 \\
\hline Leaf coiling & 0.00 & 0.00 & 0.00 & 0.07 & 0.00 & 0.07 & 100 & 1.07 & 25.01 & 25.01 & 13.82 \\
\hline Ratooning & 0.00 & 0.00 & 0.00 & 0.21 & 0.00 & 0.21 & 100 & 1.71 & 26.54 & 26.54 & 24.82 \\
\hline
\end{tabular}

IJ-124 and AWGUII-04 - landraces, Vp - phenotypic variance, Vg - genetic variance, Ve - environmental variance, $\mathrm{H}^{2}-$ broad-sense heritability, PCV - phenotypic coefficient of variation, GCV - genotypic coefficient of variation, GA - genetic advance.

and $100 \%$, respectively). All these above-mentioned traits had high genetic advance except leaf coiling and ratooning, which was 13.82 and $24.82 \%$, respectively. The traits mentioned above were, therefore, subjected to tests of goodness-of-fit to classical genetic ratios, as presented in Table 4 to determine their modes of inheritance.

\section{The goodness-of-fit test}

According to TRIPATHY et al. (2018), the nature of gene action and its heritability determines its selection success for a plant or crop improvement. The goodness-of-fit test for the six characters earlier mentioned was used to determine the gene action through conformity to classical segregation ratios and is explained below (Table 4). 
Table 3. Estimates of variance and genetic parameters of fourteen panicle traits of two landraces of rice

\begin{tabular}{|c|c|c|c|c|c|c|c|c|c|c|c|}
\hline Traits & $\begin{array}{c}\mathrm{IJ}-124 \\
\text { variance }\end{array}$ & $\begin{array}{c}\text { AWGUII-04 } \\
\text { variance }\end{array}$ & \begin{tabular}{|c|}
$\mathrm{F}_{1}$ \\
variance
\end{tabular} & $\mathrm{Vp}$ & $\mathrm{Ve}$ & $\mathrm{Vg}$ & $\mathrm{H}^{2}(\%)$ & $\begin{array}{c}\mathrm{F}_{2} \\
\text { mean }\end{array}$ & $\begin{array}{l}\mathrm{PCV} \\
(\%)\end{array}$ & $\begin{array}{l}\text { GCV } \\
(\%)\end{array}$ & GA $(\%)$ \\
\hline Panicle length & 1.39 & 0.64 & 2.42 & 12.92 & 1.48 & 11.44 & 89.0 & 23.80 & 15.10 & 14.21 & 98.98 \\
\hline Rachis length & 2.62 & 2.17 & 3.56 & 10.06 & 2.78 & 7.28 & 72.0 & 12.45 & 25.49 & 21.68 & 120.52 \\
\hline $\begin{array}{l}\text { Number of filled } \\
\text { spikelets }\end{array}$ & 452.40 & 1685.76 & 90.89 & 1940.00 & 743.02 & 1196.99 & 62.0 & 67.40 & 65.35 & 51.33 & 3658.61 \\
\hline $\begin{array}{l}\text { Number of unfilled } \\
\text { spikelets }\end{array}$ & 346.64 & 78.24 & 164.67 & 1767.31 & 196.52 & 1570.79 & 89.0 & 58.32 & 72.09 & 67.96 & 5548.78 \\
\hline $\begin{array}{l}\text { Total number of } \\
\text { spikelets }\end{array}$ & 85.44 & 2353.04 & 472.89 & 3299.34 & 970.46 & 2328.88 & 71.0 & 129.10 & 44.49 & 37.38 & 3716.02 \\
\hline Caryopsis colour & 0.00 & 0.00 & 0.00 & 0.57 & 0.00 & 0.57 & 100 & 2.24 & 33.83 & 33.83 & 52.73 \\
\hline Threshability & 0.00 & 0.00 & 0.00 & 0.26 & 0.00 & 0.26 & 100 & 2.07 & 24.77 & 24.77 & 26.19 \\
\hline $\begin{array}{l}\text { Number of primary } \\
\text { branches }\end{array}$ & 0.24 & 0.64 & 0.00 & 6.58 & 0.29 & 6.29 & 96.0 & 9.37 & 27.39 & 26.77 & 138.28 \\
\hline $\begin{array}{l}\text { Total length of } \\
\text { primary branches }\end{array}$ & 193.96 & 149.08 & 49.67 & 1022.87 & 130.90 & 891.97 & 87.0 & 94.42 & 33.87 & 31.63 & 1945.98 \\
\hline $\begin{array}{l}\text { Number of } \\
\text { secondary branches }\end{array}$ & 34.16 & 71.20 & 22.89 & 119.05 & 42.75 & 76.30 & 64.0 & 21.03 & 51.89 & 41.54 & 747.45 \\
\hline $\begin{array}{l}\text { Total length of } \\
\text { secondary branches }\end{array}$ & 432.38 & 674.50 & 364.63 & 1030.09 & 490.51 & 539.58 & 52.0 & 57.61 & 55.71 & 40.32 & 1929.42 \\
\hline $\begin{array}{l}\text { Number of tertiary } \\
\text { branches }\end{array}$ & 0.00 & 10.16 & 0.00 & 0.05 & 3.39 & -3.34 & -6895 & 0.02 & 897.78 & 7454.52 & -28057.31 \\
\hline $\begin{array}{l}\text { Total length of } \\
\text { tertiary branches }\end{array}$ & 0.00 & 36.91 & 0.00 & 0.17 & 12.30 & -12.13 & -7030 & 0.04 & 931.26 & 7808.35 & -56026.91 \\
\hline $\begin{array}{l}\text { Percentage of filled } \\
\text { spikelets }\end{array}$ & 94.42 & 4.07 & 6.53 & 593.60 & 35.01 & 558.59 & 94.0 & 52.35 & 46.54 & 45.15 & 2198.10 \\
\hline
\end{tabular}

IJ-124 and AWGUII-04 - landraces, Vp - phenotypic variance, Vg - genetic variance, Ve - environmental variance, $\mathrm{H}^{2}-$ broad-sense heritability, PCV - phenotypic coefficient of variation, GCV - genotypic coefficient of variation, GA - genetic advance.

\section{Fertility}

In the $F_{2}$ generation, segregation was distinguished, and it corresponded to the classical $\mathrm{F}_{2}$ ratio: 13 (low to moderately fertile): 3 (highly fertile) plants (Table 4 (a)). The ratio suggests that the gene responsible for fertility can be inhibited by the dominant state of another independent gene. LoNG et al. (2008) have determined that genes $\mathrm{SaF}$ and $\mathrm{SaM}^{+}$control male fertility, but the action of these two genes is suppressed, when $\mathrm{SaM}^{-}$is present, because it affects the protein structure. In essence, it suggests that the gene $S a M^{-}$inhibits fertility and, thus, supports the segregation pattern observed for spikelet fertility in our study.

\section{Tillering}

Tillering is a significant agronomic character of rice in that it determines panicle number and, there- fore, grain yield (Li et al., 2003). The number of tillers segregated into the ratio 15 (moderate to low tillering): 1 (high tillering) plants (Table 4 (b)). Even though the individual populations did not fit this ratio, the sub-total as presented under the full-sibs category conformed to the $15: 1$ ratio. It is important to note here that the high tillering plants have reduced height across the three $F_{2}$ populations. The segregating ratio (15:1) suggests that tillering is conditioned by the action of duplicate genes without cumulative effect. Nwokeocha \& Faluyi (1998) have reported the association of the dwarfing gene with high tillering, and it was confirmed in this study as tall plants tiller less than the shorter or dwarf plants. This is in agreement with Li et al. (2003), who have found that a gene $M O C 1$ affects tillering, and plant height in these plants decreases. Li et al. (2003) have also found that the genes $O S H 1$ and OsTB1, which con- 
Table 4. Test of goodness-of-fit of six agro-botanical traits to classical segregating ratios

\begin{tabular}{|c|c|c|c|c|c|c|c|c|c|c|c|c|}
\hline \multirow{2}{*}{$\begin{array}{c}\text { Populations } \\
\text { Character state }\end{array}$} & \multicolumn{3}{|c|}{ IJ-124 x AWGUII-04 (1) } & \multicolumn{3}{|c|}{ IJ-124 x AWGUII-04 (3) } & \multicolumn{3}{|c|}{ IJ-124 x AWGUII-04 (4) } & \multicolumn{3}{|c|}{ Full-sibs } \\
\hline & Observed & Expected & $\left(\chi^{2} \mathrm{cal}\right)$ & Observed & Expected & $\left(\chi^{2} \mathrm{cal}\right)$ & Observed & Expected & $\left(\chi^{2} \mathrm{cal}\right)$ & Observed & Expected & $\left(\chi^{2} \mathrm{cal}\right)$ \\
\hline \multicolumn{13}{|c|}{ a. Fertility $(3: 13)^{*}$} \\
\hline Low & 171 & 166.5625 & 0.12 & 112 & 109.6875 & 0.05 & 55 & 56.875 & 0.06 & 338 & 33.125 & 0.07 \\
\hline High & 34 & 38.4375 & 0.51 & 23 & 25.3125 & 0.21 & 15 & 13.125 & 0.27 & 72 & 76.875 & 0.31 \\
\hline Total & 205 & 205 & 0.63 & 135 & 135 & 0.26 & 70 & 70 & 0.33 & 410 & 410 & 0.38 \\
\hline \multicolumn{13}{|c|}{ b. Number of tillers (15:1) } \\
\hline Low & 224 & 212.8125 & 0.59 & 131 & 140.625 & 0.66 & 74 & 78.75 & 0.29 & 429 & 432.1875 & 0.02 \\
\hline High & 3 & 14.1875 & 8.82 & 19 & 9.375 & 9.88 & 10 & 5.25 & 4.29 & 32 & 28.8125 & 0.35 \\
\hline Total & 227 & 227 & 9.41 & 150 & 150 & 10.54 & 84 & 84 & 4.58 & 461 & 461 & 0.37 \\
\hline \multicolumn{13}{|c|}{ c. Plant growth form $(9: 6: 1)$} \\
\hline Intermediate & 69 & 84.9375 & 2.99 & 77 & 76.5 & 0.0033 & 59 & 46.6875 & 3.24 & 205 & 208.125 & 0.05 \\
\hline Compact & 75 & 56.6250 & 5.96 & 48 & 51.0 & 0.1765 & 22 & 31.1250 & 2.67 & 145 & 138.75 & 0.28 \\
\hline Open & 7 & 9.4375 & 0.63 & 11 & 8.5 & 0.7353 & 2 & 5.1875 & 1.95 & 20 & 23.125 & 0.42 \\
\hline Total & 151 & 151 & 9.58 & 136 & 136 & 0.9151 & 83 & 83 & 7.86 & 370 & 370 & 0.75 \\
\hline \multicolumn{13}{|c|}{ d. Maturity (15:1) } \\
\hline Late & 216 & 216.5625 & 0.0015 & 141 & 140.625 & 0.001 & 80 & 81.5625 & 0.03 & 447 & 448.125 & 0.0028 \\
\hline Early & 15 & 14.4375 & 0.0219 & 9 & 9.375 & 0.015 & 7 & 5.4375 & 0.45 & 31 & 29.875 & 0.0423 \\
\hline Total & 231 & 231 & 0.0234 & 150 & 150 & 0.016 & 87 & 87 & 0.48 & 478 & 478 & 0.0451 \\
\hline \multicolumn{13}{|c|}{ e. Ratooning (3:1). } \\
\hline Ratooned & 207 & 220.5 & 0.83 & 169 & 174.75 & 0.19 & 79 & 85.5 & 0.49 & 455 & 480.75 & 1.37 \\
\hline No ratoon & 87 & 73.5 & 0.57 & 64 & 58.25 & 0.57 & 35 & 28.5 & 1.48 & 186 & 160.25 & 4.14 \\
\hline Total & 294 & 294 & 3.31 & 233 & 233 & 0.76 & 114 & 114 & 2.97 & 641 & 641 & 5.51 \\
\hline \multicolumn{13}{|c|}{ f. Leaf coiling $(15: 1)$} \\
\hline No coiling & 201 & 205.3125 & 0.09 & 133 & 134.0625 & 0.0084 & 75 & 73.125 & 0.048 & 409 & 412.5 & 0.03 \\
\hline Coiled & 18 & 13.6875 & 1.36 & 10 & 8.9375 & 0.1263 & 3 & 4.875 & 0.721 & 31 & 27.5 & 0.45 \\
\hline Total & 219 & 219 & 1.45 & 143 & 143 & 0.1347 & 78 & 78 & 0.769 & 440 & 440 & 0.48 \\
\hline
\end{tabular}

* - trait segregation ratio, IJ-124xAWGUII-04 (1), (2) and (3) - $\mathrm{F}_{2}$ populations, $\chi^{2}$ cal - calculated chi-square.

trol the initiation and regulation of meristem production and growth, have reduced effect when the gene $M O C 1$ is present in rice. It has been suggested that the gene $\mathrm{MOCl}$ regulates the actions of both $\mathrm{OSHI}$ and OsTB1. Thus, it was concluded that the dominant gene $M O C 1$ reduces tillering, hence, resulting in fewer tillers in tall plants.

\section{Plant growth form}

Plant growth form is a trait that affects the efficiency of photosynthesis and ultimately grains yield for rice (FAnG et al., 2009; ABRAHAM, 2016). The plant growth form and tillering ability of a rice plant determine its architecture. FANG et al. (2009) have recognised the action of a single gene tac2, which controls tiller angle in rice and have suggested that tiller angle is a monogenic character because the segregation ratio of $3: 1$ is observed when a tac 2 mutant (open plant) is crossed with Xinong 1A (a compact plant). FANG et al. (2009), however, have concluded that since this gene, tac2, may be an allelic form of tacl gene, which has a similar phenotypic expression as tac2 plants, it is possible that plant form is controlled by these two allelic genes.

The plant form segregation pattern was as follows: 9 (intermediate): 6 (compact): 1 (open) plants (Table 4 (c)). The open or procumbent plants were categorised together, because plants with open plant form sometimes approach the procumbent form after grain-filling depending on the weight of the panicles. This ratio suggests the effect of a duplicate gene with cumulative effect. The results obtained, as stated above, agreed with FANG et al. (2009) in that the intermediate plant form is dominant over the compact and open plant form especially since all $F_{1}$ hybrids had the intermediate plant form.

\section{Maturity}

Drought tolerance in rice involves some array of traits, which includes ratooning, leaf rolling, days to maturity and stay-green. The segregation ratio for the number of days to maturity was: 15 (moderate to late 
maturing): 1 (early maturing) plants (Table 4 (d)). It was observed on the field that the early maturing plants were tall and produced fewer tillers than the late maturing ones. The segregating ratio suggested the action of a duplicate gene without cumulative effect. The implication of this is that it is the recessive state of these genes that will engender early maturity in rice. Early maturity has been identified as an attempt by a plant to escape terminal drought (YosHIDA, 1981). Hence, earliness in rice can be considered a drought-escape mechanism.

However, maturity can also be a yield-related trait. It has been earlier stated that the early maturing hybrids use the early maturity to escape a drought that may occur later in the planting season. Hence, they spend less time accumulating biomass to reach the reproduction stage quickly. This, in essence, will reduce the number of tillers produced and ultimately reduce yield.

\section{Ratooning}

Ratooning, which is the ability of the rice plant to maintain vegetative and reproductive growth or die and rejuvenate from the rootstock, was found in our study to be a dominant character in the $\mathrm{F}_{1}$. It segregated into 3 (ratooning/perennial): 1 (non-ratooning/ annual) plants in the $\mathrm{F}_{2}$, also confirming the dominant character of the ratooning gene (Table 4 (e)). Both types of ratooning were categorised together as opposed to the work of OloYedE et al. (1999). Our study, however, supports their findings in that perennial habit is dominant over annual although they found the rejuvenating from rootstock after dying back to be a recessive trait. Ratooning is of importance especially in an early maturing variety as the ratoons take less time to mature (usually less than two months). This stems from the fact that the ratoons' age starts from the age of the primordial cells from which they are developed.

\section{Leaf rolling}

Leaf coiling/rolling segregated into 15 (noncoiling): 1 (coiled) plants (Table 4 (f)). This suggests the action of a duplicate gene without cumulative effect. In the $\mathrm{F}_{3}$ (data not presented), this character was found to segregate with the stay-green character, i.e. the plants continually produced tillers or ratoons even while the original tillers were maturing. It was also observed on the field that plants with rolling leaves have stay-green characteristic, i.e. they produce tillers continually without necessarily dying to regenerate from the rootstock. CHANDRA BABU et al. (2003) have found leaf rolling/coiling to be characterised by QTLs located primarily on chromosomes 1 and secondarily on chromosomes 8 and 11. During water stress, leaf rolling reduces the leaf area exposed to sunlight, thereby, reducing evapotranspiration (NALEEM et al., 2017).

Leaf rolling, in addition to leaf angle, has been identified as an adaptive character to conserve water during drought (PANDEY and Shukla, 2015). The observations made in this study support the findings of the above researchers in that leaf rolling was found in plants with upright leaves and stay-green characters. The upright-leaf trait is much coveted in rice breeding as plants possessing this trait utilise solar radiation more efficiently than those with lax leaves (LONG et al., 2006; SARVESTANI et al., 2008). Horizontal leaves have been reported to waste energy because, at midday, the surface exposed to light absorbs radiation that is three times more than the amount required for the saturation of photosynthesis (LoNG et al., 2006). Due to this, cultivars of rice with a lower canopy of lax leaves and top canopies of erect leaves have been designed so that when the upper layer of leaves have intercepted minimal amount of energy, the remaining can be used by the lower canopy, leading to efficiency in the usage of energy by plants (LoNG et al., 2006; Evans, 2013).

\section{CONCLUSIONS}

It was established that high fertility occurs when gene $\mathrm{SaM}^{-}$is absent, and gene $\mathrm{SaF}$ is dominant in at least one locus. The high tillering and the dwarfing genes are in an adaptive gene complex and are thus inherited together. Plant form and leaf-rolling are each controlled by two dominant genes with cumulative effects. Early maturity in rice is an escape mechanism with the trade-off being lower biomass accumulation, hence, lower yield. Ratooning is, however, the desired trait in this regard as farmers can harvest at least twice in a single planting season with the advantage that the ratoons grow and nurse spikelets to maturity in a short period. Leaf-rolling and upright leaf angle were found to be associated 
with stay-green plants in the present study. However, further research should be conducted to understand the relationships amongst these traits.

Our study has, thus, been able to confirm that the six agro-botanical characters (fertility, tillering, plant form, maturity, ratooning and leaf-rolling) that are associated with yield and drought tolerance have high heritability and genetic advance. They can, therefore, be used as selection indices for hybridisation purposes. The goodness-of-fit test provided information on the segregation patterns of the traits mentioned above that will be useful for breeders in breeding programmes.

\section{ACKNOWLEDGEMENTS}

The authors wish to acknowledge Dr R.O. Akinwale of the Department of Crop Production and Protection, Obafemi Awolowo University, Ile-Ife, for his contribution to the statistical analysis of the data obtained.

\section{REFERENCES}

Aвraham O.G., 2016: Genetic analysis of yield in some selected accessions from landraces of rice (Oryza sativa Linn.) in Nigeria. - Master of Science Thesis. Department of Botany, Obafemi Awolowo University. - Ile-Ife, Nigeria.

Abraham O.G., Nwokeocha C.C., Akinwale R.O., Faluyi J.O., 2017: Screening for yield- related characters in some landrace accessions of Oryza sativa Linn. in Nigeria. - Journal of Plant Sciences, 12: 52-58.

Afiukwa C.A., Faluyi J.O, AtKinson C.J., Ubi B.E., Igwe D.O., Akinwale R.O., 2016: Screening of some rice varieties and landraces cultivated in Nigeria for drought tolerance based on phenotypic traits and their association with SSR polymorphisms. - African Journal of Agricultural Research, 11(29): 2599-2619.

Ahmad M., Iqbal M., Gul Z., Khan B.A., Kanwal A., Saleem M., Khan N.I., 2016: Genetic analysis of F2 population of tomato for quantitative traits in the cross bushbeef $x$ nagina. - Advances in Plants and Agricultural Research, 4(6): 422-424.

Akinwale M.G., Gregorio G., Nwilene F., AKinyele B.O., Ogunbayo S.A., Odiy A.C., 2011:
Heritability and correlation coefficient analysis for yield and its components in rice (Oryza sati$v a$ L.). - African Journal of Plant Science, 5(3): 207-212.

Baloch A.W., Soomro A.M., Javed M.A., Ahmed M., Bughio H.R., Bughio M.S., Mastoi N.N., 2002: Optimum plant density for yield in rice (Oryza sativa L.). - Asian Journal of Plant Sciences, 1(1): 25-27.

BIOVERSITY InTERNATIONAL, IRRI, WARDA, 2007: Descriptor for Wild and Cultivated Rice (Oryza spp.): 1-63. - Bioversity International, Rome, Italy; International Rice Research Institute, Los Banos, Philippines; WARDA, Africa Rice Centre, Cotonou, Benin.

Bolaj A.O., NwoKeocha C.C., 2013: Issues concerning reproductive isolation in rice hybrid swarm involving Oryza sativa Linn., O. longistaminata A. Chev. et Roehr. and O. glaberrima Steud. Located in Jebba Nigeria. - International Journal of Biological and Chemical Sciences, 7(5): 2040-2049.

Chandra Babu R., Nguyen B.D., Chamarerk V., Shanmugasundaram P., Chezhian P., JeyapraKash P., Ganesh S.K., Palchamy A., Sadasivam S., Sarkarung S., Wade L.J., NGuyen H.T., 2003: Genetic Analysis of Drought Resistance in Rice by Molecular Markers: Association between Secondary Traits and Field Performance. - Crop Science, 43: 1457-1469.

Evans J., 2013: Topical reviews on photosynthesis improvement: improving photosynthesis. - Plant Physiology, 162: 1780-1793.

Fageria N.K., Moreira A., Coelho A.M., 2011: Yield and yield components of upland rice as influenced by nitrogen sources. - Journal of Plant Nutrition, 34: 361-370.

Faluyi J.O., NwoKeocha C.C., 1993: Agro-botanical studies of some populations of the Oryza sativaOryza glaberrima complex of peasant agriculture. - Nigerian Journal of Botany, 6: 1-11.

FAng L., SANG X., YAng Z., Lin Y., Wan N., He G., 2009: Genetic analysis and gene mapping of a rice tiller angle mutant tac2. - Rice Science, 16(4): 323-326.

Futsuhara Y., Kondo S., Kitano H., Mir M., 1979a: Genetic studies on dense and lax panicles in rice. I. Character expression and mode of lax panicle rice. - Japan Journal of Breeding, 29(2): 151-158. 
Futsuhara Y., Kondo S., Kitano H., Mir M., 1979b: Genetic studies on dense and lax panicles in rice. II. Character expression ad mode of inheritance of dense panicle rice. - Japan Journal of Breeding, 29(3): 239-247.

GHESQUiere A., 1986: Evolution of Oryza longistaminata. - Proceedings of the International Rice Genetics Symposium, 15-25.

Kumar S., Chauhan M.P., Tomar A., Kasana R.K., 2018: Coefficient of variation (GCV \& PCV), heritability and genetic advance analysis for yield contributing characters in rice (Oryza sativa L.). Journal of Pharmacognosy and Phytochemistry, 7(3): 2161-2164.

Li X., Qian Q., Fu Z., Wang Y., Xiong G., Zeng F., Wang X., Liu X., Teng S., Hiroshi F., Yuan M., Luok D., Han B., Li J., 2003: Control of tillering in rice. - Nature, (422): 618-621.

Long S.P., Zhu X., Naidu S.L., Ort D.R., 2006: Can improvement in photosynthesis increase crop yields? - Plant, Cell and Environment, 29: 315330.

Long Y., Zhao L., Niu B., Su J., Wu H., Chen Y., Zhang Q., Guo J., Zhuang C., Mei M., XIa J., Wang L., Wu H., LiU Y.G., 2008: Hybrid male sterility in rice controlled by the interaction between divergent alleles of two adjacent genes. Proceedings of National Academic in Sciences USA, 105(48): 18871-18876.

Neelam K., Sahi G.K., Kumar K., Singh K., 2017: Identification of drought stress tolerance in wild species germplasm of rice based on leaf and root morphology. - Plant Genetic Resources, 1-7.

NwOKeOCha C.C., Faluyi J.O., 1998: Inheritance of dwarfness in a selection from local (Nigerian) germplasm of Oryza sativa Linn. - Nigerian Journal of Genetics, 13:6-12.

Nwokeocha C.C., Faluyi J.O., Aladejana F.O., 2007: Cytogenetic studies in the ABC genome of the genus Oryza Linn. - Research Journal of Botany, ISSN 1816-4919.

Ока H.I., Chu Y.E., 1970: Introgression across isolating barriers in wild and cultivated Oryza species. - Evolution, 24: 61-72.

Oloyede F.A., Nwokeocha C.C., Faluyi J.O., 1999: Genetic studies of perennial habit in some species of the genus Oryza. - Nigerian Journal of Botany, 12(2): 169-174.
Pandey S., Bhandari H., 2009: Drought, coping mechanism and poverty: Insights from rainfed rice farming in Asia: Occasional Paper, 7. - International Fund for Agricultural Development (IFAD).

Pandey V., Shukla A., 2015: Acclimation and tolerance strategies of rice under drought stress. Rice Science, 22(4): 147-161.

Robinson H.H., 1966: Quantitative genetics in relation to breeding on the centennial of medalism. Indian Journal of Genetics, 26: 171-187.

Rosenzweig C., Iglesias A., Yang X.B., Epstein P.R., Chivian E., 2000: Climate change and U.S. agriculture: The impacts of warming andextreme weather events on productivity, plant diseases, and pests.- Center for Health and the Global Environment, Harvard Medical School, Boston.

Sano Y., Sano R., Morishima H., 1984: Neighbour effects between co-occurring rice species, Oryza sativa and $O$. glaberrima. - Journal of Applied Ecology, 21: 245-254.

Sarangui D.N., Pradhan B., Sial P., Mishra C.H.P., 2009: Genetic variability, correlation and pathcoefficient analysis in early rice genotypes. - Environment and Ecology, 27(1A): 307-312.

Sarvestani Z.T., Pirdashti H., Sanavy S.A.M.M., Balouchi H., 2008: Study of water stress in different growth stages on yield and yield components of different rice (Oryza sativa L.) cultivars. Pakistan Journal of Biological Sciences, 11(10): 1303-1309.

Singh N.K., Singh A.K., Sharma C.L., Singh P.K., Singh O.N., 2007: Study of heterosis in rice using line $x$ tester mating system. - Oryza, 44(3):260-263.

Singh Y., Pani D.R., Pradhan S.K., BajPai A., Singh U.S., 2008: Divergence analysis for quality traits in some indigenous basmati rice genotypes. Oryza, 45(4): 263-267.

Srividhya A., Vemireddy L.R., Sridhar S., JaYaprada M., Ramanarao P.V., Hariprasad A.S., Reddy H.K., Anuradha G., SiddiQ E., 2011: Molecular mapping of QTLs for yield and its components under two water supply conditions in rice (Oryza sativa L.). - Journal of Crop Science and Biotechnology, 14: 45-56.

Suman A., Sankar V.G., Rao L.V.S., Sreedhar N., 2005: Variability, heritability and genetic advance in rice. - Crop Research, 30(2): 211-214. 
Tripathi N., Verma O.P., Singh P.K., Rajpoot P., 2018: Studies on genetic variability, heritability and genetic advance in rice (Oryza sativa L.) for yield and its components under salt-affected soil. - International Journal of Current Microbiology and Applied Sciences, 7: 5316-5324.

Umunnakwe E.C., 2015: Collection, characterization and evaluation of selected genetic resources from landraces of Oryza sativa Linn. - Master of Science Thesis.Department of Botany, Obafemi Awolowo University. - Ile-Ife, Nigeria.

Yoshida S., 1981: Fundamentals of Rice Crop Science: 1-230. - Manila.

ZEven A.C., 1998: Landraces: A review of definitions and classifications. - Euphytica, 104: 127-139.

\section{DVIEJŲ RYŽIŲ VEISLIŲ AGROBOTANINIŲ DERLINGUMO IR TOLERANCIJOS SAUS- RAI POŽYMIŲ PAVELDIMUMAS}

\section{Olubukola Grace Abraham, Chinyere Constance Nwokeocha, Julius Olaoye Faluyi}

\section{Santrauka}

Tyrimas buvo atliktas siekiant padèti selekcininkams ir ūkininkams racionaliau vykdyti ryžių hibridizaciją ir jų auginimą. Buvo aprašyta ir ịvertinta dviejų vietinių ryžių veislių, AWGUII-04 ir IJ-124, požymių, susijusių su derliumi ir sausros tolerancija, fenotipinis ịvairavimas, paveldimumas ir genetinis kintamumas. Tirti agrobotaniniai požymiai, susiję su derliumi, buvo pilnų varpučių dalis, augalo forma, krūmijimasis, o su sausros tolerancija - lapų susisukimas, augalų atžèlimas ir jų branda. Hibridizacijos dèka buvo sukurti trys F1 hibridai, kurie pasiekè F2 kartą. Kiekybiniai ir kokybiniai morfologiniu bei reprodukcinių požymių duomenys buvo surinkti tirtose F2 populiacijose. Gauti rezultatai parodè, kad visi tirti požymiai buvo paveldimi (62-100\%) F2 kartoje. Visų tikslinių savybių, išskyrus lapų susisukimą, genetinis kintamumas buvo didesnis nei $20 \%$. Dẻl aukšto tirtų požymių paveldimumo jie gali būti traktuojami kaip patikimi tolesnejje ryžių derliaus gerinimo strategijoje. 